\title{
Pengaruh Pemberian Pakan dengan Sumber Protein Berbeda terhadap Persentase Potongan Karkas dan Massa Protein Daging Ayam Lokal Persilangan
}

\section{Effect of Feeding with Different Protein Sources on the Carcass Cut Percentage and Protein Mass of Local Cross Chicken}

\author{
H. Pratiwi*, U. Atmomarsono dan D. Sunarti \\ Fakultas Peternakan dan Pertanian, Universitas Diponegoro, Semarang, 50275 \\ *E-mail: henipratiwi033@gmail.com
}

(Diterima: 26 Oktober 2016; Disetujui: 19 Desember 2016)

\begin{abstract}
ABSTRAK
Tujuan dari penelitian ini adalah mengetahui pengaruh pemberian pakan dengan sumber protein berbeda terhadap persentase potongan karkas dan massa protein daging ayam lokal persilangan. Materi yang digunakan adalah 126 ekor ayam lokal persilangan (unsexed) umur2 minggu dengan bobot badan 129 $\pm 6,34 \mathrm{~g}$. Bahan pakan yang digunakan yaitu jagung, bekatul, bungkil kedelai, tepung ikan, MBM (Meat bone meal) dan PMM (Poultry meat meal). Rancangan percobaan yang digunakan adalah RAL (Rancangan acak lengkap) dengan 3 perlakuan dan 7 ulangan. Perlakuan yang diberikan yaitu $\mathrm{T} 1=2$ sumber protein (tepung ikan dan bungkil kedelai), T2 = 3 sumber protein (tepung ikan, bungkil kedelai, dan MBM), T3 = 4 sumber protein (tepung ikan, bungkil kedelai, MBM dan PMM). Pemberian pakan menggunakan metode bebas memilih dan perlakuan dimulai pada umur 2 minggu sampai 10 minggu. Parameter yang diamati adalah bobot akhir, bobot potongan karkas, persentase potongan karkas dan massa protein daging. Data yang diperoleh dianalisis ragam dengan uji $\mathrm{F}$ dengan taraf $5 \%$ dan pada penelitian ini terdapat pengaruh perlakuan sehingga dilanjutkan dengan uji jarak berganda duncan. Hasil penelitian menunjukkan bahwa pemberian pakan dengan sumber protein berbeda berpengaruh nyata $(\mathrm{P}<0,05)$ terhadap bobot akhir, bobot potongan karkas dan massa protein daging serta tidak berpengaruh nyata $(\mathrm{P}>0,05)$ terhadap persentase potongan karkas. Kesimpulan penelitian ini adalah pemberian pakan dengan sumber protein yang semakin beragam dapat meningkatkan bobot akhir, bobot potongan karkas dan massa protein daging serta memberikan hasil yang sama pada persentase potongan karkas ayam lokal persilangan.
\end{abstract}

Kata kunci: sumber protein, potongan karkas, massa protein, ayam lokal persilangan

\section{ABSTRACT}

The research aims to study the effect of feeding with different protein sources on the carcass cut percentage and protein mass of local cross chicken. The materials used were 126 unsexed of local cross chicken, 2 weeks age with body weight $129 \pm 6.34$ g. Feedstuffs used were corn, rice brand, soybean meal, fish meal, meat bone meal and poultry meat meal. The research design used was completely randomized design (CRD) with 3 treatments and 7 replications. The treatments were $T 1=2$ protein sources (fish meal dan soybean meal) $T 2=3$ protein sources (fish meal, soybean meal and meat bone meal), T3=4 protein sources (fish meal, soybean meal, meat bone meal and poultry meat meal). The research used was free choice feeding method and the treatments were applied started from 2 weeks age until 10 weeks age. Parameter measured were final body weight, carcass cut weight, carcass cut percentage and protein mass. Data was analyzed by variety of $F$ test at the level of 5\%, followed by Duncan test when there is significant effect of the treatment. The result showed that the treatment of feeding with different protein sources do influence significantly $(P<0.05)$ on final body weight and protein mass but on carcass cut percentage parameter showed that the treatment do not influence significantly $(P>0.05)$. The conclusion of the experiment is feeding with the variety of protein sources can increasing on final body weight, carcass cut weight and protein mass and give the same result on carcass cut percentage of local cross chicken.

Keywords: protein sources, carcass cuts, protein mass, local cross chicken

Pengaruh Pemberian Pakan dengan ... (Pratiwi et al.) 


\section{PENDAHULUAN}

Daging ayam lokal banyak diminati masyarakat karena memiliki rasa yang khas, akan tetapi ayam lokal memiliki pertumbuhan relatif lambat dan produktivitas yang rendah, sehingga diperlukan suatu upaya untuk meningkatkan produktivitas ayam lokal. Peningkatan produktivitas tersebut dapat dilakukan melalui persilangan. Ayam lokal pejantan yang disilangkan dengan ayam ras petelur betina dikenal dengan ayam lokal persilangan, dimana memiliki pertumbuhan yang lebih cepat dan produksi daging yang dihasilkan lebih tinggi dari ayam lokal.

Menurut hasil penelitian kebutuhan nutrisi ayam lokal persilangan masih bervariasi sehingga diperlukan suatu metode untuk menghitung kebutuhan nutrisi ayam lokal persilangan yaitu dengan pemberian pakan bebas memilih. Metode pemberian pakan bebas memilih merupakan suatu metode pemberian pakan dimana ayam bebas memilih pakan yang tersedia (Fanatico et al., 2013). Ayam memiliki kemampuan mengkonsumsi pakan sesuai dengan kebutuhannya, dengan pemberian pakan bebas memilih ayam dapat memilih pakan yang telah disediakan sehingga kebutuhan nutrisi ayam lokal persilangan dapat diketahui (Kompiang et al., 2001).

Pakan berperan untuk kelangsungan hidup pokok dan produksi, pakan yang diberikan harus mengandung protein dalam jumlah yang sesuai, apabila kebutuhan protein tidak terpenuhi dapat mengakibatkan penurunan pertumbuhan dan apabila protein berlebih menyebabkan pakan yang diberikan tidak efisien. Protein merupakan bahan utama pembentukan karkas. Pemberian pakan dengan sumber protein hewani memberikan performa yang lebih baik dari nabati (Hossain et al., 2013), tetapi apabila kedua sumber protein tersebut diberikan secara bersamaan akan saling melengkapi, sehingga keseimbangan asam amino dapat tercapai. Ketersediaan protein dalam pakan sangat berkaitan dengan bobot akhir, hal ini karena protein berperan penting terhadap pembentukan karkas.
Massa protein daging merupakan salah satu indikator yang menunjukkan seberapa besar deposisi protein pada ternak, semakin tinggi nilai massa protein daging maka semakin baik (Fanani et al., 2016). Hal ini berarti protein pakan yang didistribusikan ke dalam jaringan tubuh semakin tinggi. Konsumsi protein yang tinggi diikuti dengan asupan protein yang tinggi maka semakin tinggi pula protein yang dideposisikan menjadi daging.

Tujuan dari penelitian ini adalah mengetahui pengaruh pemberian pakan dengan sumber protein berbeda terhadap persentase potongan karkas dan massa protein daging ayam lokal persilangan.

\section{METODE}

\section{Tempat penelitian}

Penelitian ini dilaksanakan pada bulan November 2016 - Januari 2017 di kandang penelitian Produksi Ternak Unggas Fakultas Peternakan dan Pertanian, Universitas Diponegoro, Semarang.

\section{Materi penelitian}

Materi yang digunakan dalam penelitian ini adalah 126 ekor ayam hasil persilangan ayam bangkok dengan ayam ras petelur (unsexed) umur 2 minggu dengan bobot badan $129 \pm 6,34$ g. Kandang yang digunakan yaitu kandang tipe slat terdiri dari 21 unit percobaan dengan masing-masing unit percobaan berisi 6 ekor ayam. Bahan pakan sumber energi yang digunakan adalah jagung dan bekatul, bahan pakan sumber protein yang digunakan adalah tepung ikan, bungkil kedelai, MBM (Meat Bonemeal), PMM (Poultry Meat Meal) dan CaCO3. Kandungan nutrisi bahan pakan yang digunakan dalam penelitian terdapat pada Tabel 1 .

\section{Rancangan penelitian}

Rancangan yang digunakan adalah RAL (Rancangan acak lengkap) dengan 3 perlakuan dan 7 ulangan.

Perlakuan yang diberikan dalam 
Tabel 1. Kandungan nutrisi bahan pakan berdasarkan kering udara.

\begin{tabular}{lccccccc}
\hline Bahan Pakan & $\begin{array}{c}\text { EM } \\
(\mathrm{kkal} / \mathrm{kg})^{4}\end{array}$ & $\begin{array}{c}\text { PK } \\
(\%)^{1}\end{array}$ & $\begin{array}{c}\text { SK } \\
(\%)^{1}\end{array}$ & $\begin{array}{c}\text { Lisin } \\
(\%)^{3}\end{array}$ & $\begin{array}{c}\text { Metionin } \\
(\%)^{3}\end{array}$ & $\begin{array}{c}\mathrm{Ca} \\
(\%)^{2}\end{array}$ & $\begin{array}{c}\text { P } \\
(\%)^{1}\end{array}$ \\
\hline Jagung & 3796 & 6,54 & 2,15 & 0,34 & 0,21 & 0,03 & 0,20 \\
Kuning & 3643 & 10,86 & 7,55 & 0,58 & 0,22 & 0,00 & 1,53 \\
Bekatul & 3213 & 45,76 & 3,97 & 2,98 & 0,70 & 0,05 & 0,39 \\
Bungkil kedelai & 2986 & 31,51 & 1,82 & 6,56 & 2,56 & 6,42 & 2,04 \\
Tepung ikan & 2770 & 58,49 & 1,07 & 3,45 & 0,75 & 9,08 & 4,14 \\
MBM & 3555 & 43,08 & 7,82 & 1,19 & 0,54 & 1,01 & 2,12 \\
PMM & 0 & 0,00 & 0,00 & 0,00 & 0,00 & 80,00 & 0,00 \\
$\mathrm{CaCO}_{3}$ &
\end{tabular}

Sumber: ${ }^{1}$ Hasil analisis Proksimat di PT. Sidomuncul, Ungaran (2016).

${ }^{2}$ Hasil analisis di Laboratorium Ilmu Nutrisi dan Pakan, Fakultas Peternakan dan Pertanian, Universitas Diponegoro, Semarang (2016).

${ }^{3}$ Hartadi (1980).

${ }^{4}$ Hasil perhitungan menggunakan Bomb Calorimeter di Laboratorium Ilmu Nutrisi dan Pakan, Fakultas Peternakan dan Pertanian, Universitas Diponegoro, Semarang (2016).

penelitian ini yaitu :

$\mathrm{T} 1=$ Dua sumber protein (tepung ikan dan bungkil kedelai).

T2 = Tiga sumber protein (tepung ikan, bungkil kedelai, dan MBM).

$\mathrm{T} 3$ = Empat sumber protein (tepung ikan, bungkil kedelai, MBM dan PMM).

Data yang diperoleh dianalisis ragam dengan uji $\mathrm{F}$ dengan taraf $5 \%$ dan apabila terdapat pengaruh perlakuan maka dilanjutkan dengan uji jarak berganda Duncan (Stell dan Torrie, 1981).

\section{Tahapan penelitian}

1. Persiapan kandang dan peralatan.

2. Pakan perlakuan diberikan secara ad libitum dan menggunakan metode bebas memilih dimana 1 tempat pakan berisi 1 bahan pakan.

3. Pencatatan konsumsi dan sisa pakan dilakukan setiap hari dan penimbangan ayam dilakukan setiap minggu.

4. Penimbangan ayam pada umur 10 minggu untuk memperoleh data bobot akhir.

5. Pemotongan dilakukan dengan cara mengambil ayam pada setiap unit percobaan sebanyak 2 ekor secara acak. Pemotongan ayam dilaksanakan dengan cara memotong bagian arteri carotis, vena jugularis dan esofagus. Pencabutan bulu, mencelupkan ayam ke dalam air panas, membersihkan ayam dari bulu, memotong kaki, kepala dan mengeluarkan organ dalam. Menimbang karkas untuk mendapatkan bobot karkas. Memotong karkas menjadi beberapa potongan komersial meliputi sayap, dada, paha atas, paha bawah, punggung depandan punggung belakang. Menimbang masingmasing bagian untuk mendapatkan bobot potongan karkas.

6. Massa protein daging diperoleh dengan cara mengambil sampel daging pada penyembelihan ayam umur 10 minggu sebanyak 2 ekor secara acak pada setiap unit percobaan. Sampel daging yang diambil adalah bagian paha dan dada yang telah dipisahkan dari tulang dan kulit. Daging dihaluskan dan dicampur kemudian diambil sampel untuk dianalisis kadar protein daging.

\section{Parameter yang diamati}

Parameter yang diamati dalam penelitian ini adalah :

1. Bobot badan akhir, diperoleh dengan cara menimbang ayam pada umur 10 minggu.

2. Bobot potongan karkas, diperoleh dengan cara memotong dan menimbang potongan karkas yang meliputi sayap, dada, paha atas, paha bawah, punggung depan dan punggung belakang. 
3. Persentase potongan karkas, diperoleh dengan membandingkan bobot potongan karkas dengan bobot karkas dan dikalikan $100 \%$.

4. Massa protein daging, dihitung berdasarkan rumus Suthama (2003) yang dikutip oleh Abdurrahman et al. (2016) yaitu dengan mengkalikan kadar protein daging (\%) dengan bobot daging $(\mathrm{g})$.

\section{HASIL DAN PEMBAHASAN}

Hasil analisis ragam menunjukkan bahwa pemberian pakan dengan sumber protein berbeda berpengaruh nyata $(\mathrm{P}<0,05)$ terhadap bobot akhir, bobot potongan karkas dan massa protein daging serta tidak berpengaruh nyata $(\mathrm{P}>0,05)$ terhadap persentase potongan karkas. Hasil dapat dilihat pada Tabel 2.

\section{Pengaruh Perlakuan terhadap Bobot Akhir}

Bobot akhir yang berbeda nyata dipengaruhi oleh asupan protein yang berbeda nyata. T3 dengan sumber protein berupa bungkil kedelai, tepung ikan, MBM dan PMM menghasilkan bobot akhir yang tertinggi dibandingkan dengan T2 dengan sumber protein berupa bungkil kedelai, tepung ikan dan MBM serta T1 dengan sumber protein berupa bungkil kedelai dan tepung ikan. Pemberian pakan dengan sumber protein yang semakin beragam tersebut mampu saling melengkapi sehingga keseimbangan asam amino dapat tercapai dan bobot akhir dapat tercapai optimal. Wahju (2004) menyatakan bahwa bahan pakan sumber protein hewani memiliki kandungan kalsium, fosfor, vitamin B kompleks, lisin dan methionin yang tinggi.

Bobot akhir T2 tidak berbeda nyata dengan $\mathrm{T} 1$ hal ini dipengaruhi oleh konsumsi asam amino. Pemberian pakan sumber protein hewani berupa tepung ikan dan MBM pada T2 menunjukkan hasil yang sama dengan pemberian tepung ikan saja pada T1. Konsumsi asam amino lisin dan methionin yang berasal dari tepung ikan dan MBM pada T2 berbeda dengan konsumsi asam amino lisin dan metionin dari tepung ikan pada $\mathrm{T} 1$, akan tetapi meskipun konsumsi asam amino lisin dan metionin T2 dan T1 berbeda kedua perlakuan tersebut menunjukkan

Tabel 2. Rata-rata bobot akhir, bobot potongan karkas, persentase potongan karkas dan massa protein daging ayam lokal persilangan.

\begin{tabular}{lccc}
\hline \multirow{2}{*}{ Parameter } & \multicolumn{3}{c}{ Perlakuan } \\
\cline { 2 - 4 } & $\mathrm{T} 1$ & $\mathrm{~T} 2$ & $\mathrm{~T} 3$ \\
\hline Bobot akhir (g/ekor) & $820,88^{\mathrm{b}}$ & $890,93^{\mathrm{b}}$ & $1.016,31^{\mathrm{a}}$ \\
Bobot dada (g) & $127,07^{\mathrm{b}}$ & $137,36^{\mathrm{b}}$ & $171,43^{\mathrm{a}}$ \\
Persentase dada (\%) & 25,73 & 25,58 & 26,38 \\
Bobot sayap (g) & $77,79^{\mathrm{b}}$ & $85,14^{\mathrm{b}}$ & $100,07^{\mathrm{a}}$ \\
Persentase sayap (\%) & 15,75 & 15,85 & 15,42 \\
Bobot punggung depan (g) & $51,86^{\mathrm{b}}$ & $58,93^{\mathrm{b}}$ & $66,50^{\mathrm{a}}$ \\
Persentase punggung depan (\%) & 10,50 & 10,98 & 10,24 \\
Bobot punggung belakang (g) & $73,07^{\mathrm{b}}$ & $79,29^{\mathrm{b}}$ & $93,57^{\mathrm{a}}$ \\
Persentase punggung belakang (\%) & 14,83 & 14,78 & 14,41 \\
Bobot paha atas (g) & $84,50^{\mathrm{b}}$ & $91,21^{\mathrm{b}}$ & $113,36^{\mathrm{a}}$ \\
Persentase paha atas (\%) & 17,10 & 16,96 & 17,47 \\
Bobot paha bawah (g) & $77,93^{\mathrm{b}}$ & $85,07^{\mathrm{b}}$ & $104,21^{\mathrm{a}}$ \\
Persentase paha bawah (\%) & 15,77 & 15,84 & 16,03 \\
Masa protein daging (g) & $70,25^{\mathrm{b}}$ & $79,51^{\mathrm{b}}$ & $100,92^{\mathrm{a}}$ \\
\hline
\end{tabular}

Keterangan: Superskrip yang berbeda pada baris yang sama menunjukkan adanya perbedaan yang nyata $(\mathrm{P}<0,05)$. 
bobot akhir yang tidak berbeda nyata, hal ini menunjukkan bahwa pemberian pakan dengan sumber protein berupa tepung ikan mampu menggantikan MBM sebagai sumber protein hewani. Karimi (2006) menyatakan bahwa tepung ikan merupakan sumber protein yang memiliki nilai biologis yang tinggi dan kaya akan asam amino terutama lisin.

Ayam lokal persilangan umur 10 minggu memiliki bobot akhir 820,88-1016,31 g. Hasil ini lebih tinggi dari penelitian Kususiyah (2011) bahwa ayam lokal persilangan umur 10 minggu bobot akhir sebesar 728,15 g dan hampir sama dengan hasil penelitian Trisiwi (2016) ayam kampung super umur 10 minggu yang diberi pakan komersial BR-1 dengan PK $21,13 \%$ dan EM $3000 \mathrm{Kcal} / \mathrm{kg}$ memiliki bobot akhir sebesar 899,55 g.

\section{Pengaruh Perlakuan terhadap Bobot Potongan Karkas}

Bobot potongan karkas berbeda nyata (Tabel 2) hal ini berarti pemberian pakan dengan sumber protein berbeda memberikan pengaruh yang berbeda antar perlakuan. T3 dengan 4 sumber protein menghasilkan bobot potongan karkas yang paling tinggi dari T2 dengan 3 sumber protein dan T1 dengan 2 sumber protein, hal ini menunjukkan bahwa penggunaan sumber protein yang semakin beragam maka produksi karkas yang dihasilkan akan semakin meningkat. Rohaeni (2015) menyatakan bahwa perlakuan pakan dengan PMM menghasilkan pertambahan bobot badan yang lebih tinggi dibandingkan dengan perlakuan bungkil kedelai. Bobot potongan karkas yangdihasilkan berbeda nyata, hal ini dipengaruhi oleh kecernaan dan retensi nitrogen.

Hasil penelitian ini menunjukkan bahwa kecernaan protein tidak berbeda nyata akan tetapi retensi nitrogen berbeda nyata. Semakin banyak nitrogen yang diserap di dalam tubuh maka bobot badan yang dihasilkan semakin tinggi. Bobot badan yang tinggi akan diikuti bobot potongan karkas yang tinggi pula. Fanani et al. (2016) menyatakan bahwa meningkatnya retensi nitrogen dapat mempengaruhi pertumbuhan dan meningkatkan bobot badan yang dihasilkan.

Protein hewani seperti PMM memiliki kandungan asam amino lisin dan metionin yang cukup, MBM memiliki kandungan asam amino metionin dan cystin yang sedikit tetapi memiliki lisin yang tinggi, sedangkan tepung ikan juga memiliki lisin dan methionin yang tinggi, asam amino lisin dan methionin berperan dalam pertumbuhan tulang dan daging. Hossain et al. (2013) menyatakan bahwa penggunaan protein hewani dapat menghasilkan bobot badan yang lebih tinggi, hal ini karena sumber protein hewani memiliki kecernaan protein yang tinggi dan berperan dalam perkembangan tulang. Protein pakan berperan untuk pertumbuhan tulang, ayam membutuhkan nutrisi yang cukup untuk proses pertumbuhan tulang. Menurut Rizkuna et al. (2014) lisin sangat berkaitan dengan proses pertumbuhan sel tulang, $\mathrm{Ca}$ dibantu oleh protein dan lisin dalam proses penyerapan kemudian dimanfaatkan untuk pembentukan tulang. Menurut Hickling et al. (1990) penambahan lisin dan methionin dapat meningkatkan bobot dada.

\section{Pengaruh Perlakuan terhadap Persentase Potongan Karkas}

Persentase potongan karkas (Tabel 2) yang tidak berbeda nyata menunjukkan bahwa pada masing-masing bagian tubuh ternak memiliki kecepatan pertumbuhan yang relatif sama sejalan dengan ukuran tubuhnya sehingga antar perlakuan diperoleh hasil yang tidak berbeda nyata. Muiz (2016) menyatakan bahwa masing-masing bagian tubuh ternak memiliki tingkat pertumbuhan sesuai dengan fungsi dari bagian tubuh tersebut. Faktor yang mempengaruhi ukuran tubuh ternak adalah genetik, umur, kondisi fisiologis ternak dan konsumsi protein.

Hasil penelitian diperoleh bahwa persentase potongan karkas ayam lokal persilangan umur 10 minggu bagian dada sebesar $25,89 \%$, sayap $15,68 \%$, punggung depan $10,57 \%$, punggung belakang $14,67 \%$, 
paha atas $17,17 \%$ dan paha bawah $15,88 \%$. Urutan persentase potongan karkas dari tertinggi sampai terendah yaitu bagian dada, paha atas, paha bawah, sayap, punggung belakang dan punggung depan. Muryanto et al. (2002) menyatakan bahwa urutan persentase potongan karkas dari tertinggi sampai terendah meliputi bagian dada $24,20 \%$, paha atas $19 \%$, paha bawah $18 \%$, sayap $15,81 \%$, punggung belakang $12,10 \%$ dan punggung depan $11 \%$.

\section{Pengaruh Perlakuan terhadap Massa Protein Daging}

Berdasarkan Tabel 2 ditunjukkan bahwa massa protein daging berbeda nyata. Massa protein daging T3 dengan 4 sumber protein memberikan hasil yang paling tinggi dari T2 dengan 3 sumber protein dan T1 dengan 2 sumber protein. Pemberian pakan dengan sumber protein yang semakin beragam menghasilkan massa protein daging yang semakin tinggi. Hal ini berkaitan dengan konsumsi protein dan asam amino, konsumsi asam amino yang cukup tentunya akan menghasilkan kadar protein daging yang optimal. Adnyana et al. (2014) bahwa asam amino merupakan bahan utama dalam proses pembentukan daging. Fanani et al. (2016) bahwa massa protein daging merupakan tingkat deposisi protein di dalam tubuh ternak.

Besarnya massa protein daging dipengaruhi oleh kadar protein daging, bobot daging yang dihasilkan dan kadar lemak dalam tubuh. Kadar lemak tubuh dalam penelitian ini menunjukkan hasil yang tidak berbeda nyata, hal ini berarti karkas yang dihasilkan berkualitas baik. Karkas yang baik mengandung banyak daging dan sedikit lemak. Griffith et al. (1998) menyatakan bahwa lemak tubuh berkorelasi positif dengan lemak karkas, apabila lemak tubuh rendah maka lemak karkas juga rendah.

Massa protein daging menunjukkan seberapa besar deposisi protein didalam tubuh, konsumsi protein yang tinggi diikuti dengan asupan protein yang tinggi hal ini berarti semakin banyak protein yang dideposisikan menjadi daging.Deposisi protein merupakan banyaknya protein yang diserap dikurangi protein yang dimanfaatkan oleh tubuh dimana tingkat deposisi protein dipengaruhi oleh ketersediaan protein dan energi didalam pakan, energi berperan dalam proses sintesis protein. Suthama (2003) bahwa protein dan energi memiliki peranan yang sangat penting dalam proses sintesis protein.

Berdasarkan hasil penelitian massa protein daging sebesar 70,25-100,92 g. Hasil ini lebih tinggi dari penelitian Abdurrahman et al. (2016) yaitu massa protein daging sebesar $62,91 \mathrm{~g}$.

\section{KESIMPULAN}

Berdasarkan hasil penelitian dapat disimpulkan bahwa pemberian pakan dengan sumber protein yang semakin beragam pada ayam lokal persilangan dapat meningkatkan bobot akhir, bobot potongan karkas dan massa protein daging serta memberikan hasil yang sama pada persentase potongan karkas.

\section{DAFTAR PUSTAKA}

Abdurrahman, Z. H., Y. B. Pramono dan N. Suthama. 2016. Feeding effect of inulin derived from dahlia tuber combined with lactobaccilus. sp on meat protein mass of crossbred kampong chicken. J. Indonesian Trop. Anim. Agric. 41(1) : $37-44$.

Adnyana, I. G. S., G. A. M. K. Dewi dan M. Wirapartha. 2014. Pengaruh imbangan energi dan protein ransum terhadap karkas ayam kampung betina umur 30 minggu. J. Tropic. Anim. Sci. 2 (3): 415-53.

Fanani, A. F., N. Suthama dan B. Sukamto. 2016. Efek penambahan umbi bunga dahlia sebagai sumber inulin terhadap kecernaan protein dan produktivitas ayam lokal persilangan. J. Kedokteran Hewan. 10 (1): $58-62$.

Fanatico, A. C., V. B. Brewer, C. M. O. Hanning dan D. J. Donoghue. 2013. Free choice feeding of free range meat 
chickens. J. Appl. Poult. Res. 22 : 750 -758 .

Griffiths, L., S. Leeson dan J. D. Summers. 1998. Studies and abdominal fat with four commercial strain of male broiler chicken. Poultry Sci. 1998-1203.

Hossain, M. A., A. F. Islam dan P. A. Iji. 2013. Growth responses, excreta quality, nutrient digestibility, bone development and meat yield traits of broiler chickens fed vegetable or animal protein diets. South African J. Anim. Sci. 43 (2) : 208-218.

Hickling, D., W. Guenter dan M. E. Jackson. 1990. The effects of dietary methionine and lysine on broiler chicken performance and breast meat yield. Can. J. Anim Sci. 70 : 673-678.

Karimi, A. 2006. The Effects of Varying Fishmeal Inclusion Levels (\%) on Performance of Broiler Chicks. J. Int. Poultry. Sci. 5 (3): 255-258

Kompiang, I. P., Supriyati, M. H. Togatorop, dan S. N. Jarmani. 2001. Kinerja ayam kampung dengan sistem pemberian pakan secara memilih dengan bebas. J. Ilmu Ternak dan Veteriner. 6 (2) : 94 101.

Kususiyah. 2011. Performans pertumbuhan ayam peraskok sebagai ayam potong belah empat serta nilai income over feed and chick cost. J. Sains Peternakan Indonesia. 6 (2): $83-87$.

Muiz, A. 2016. Pengaruh penggunaan Tepung Daun Binahong (Andredera cordifolia) sebagai feedadidtive terhadap kualitas karkas ayam pedaging. J.Agrisains. 17 (1): 54- 61.

Muryanto, P. S. Hardjosworo, R. Herman dan H. Setijanto. 2002. Evaluasi karkas hasil persilangan antara ayam kampung jantan dengan ayam ras petelur betina. J. Anim Production. 4(2) : 71-76.

Rizkuna, A., U. Atmomarsono dan D. Sunarti. 2014. Evaluasi pertumbuhan tulang ayam kampung umur 0-6 minggu dengan taraf protein dan suplementasi lisin dalam ransum. J. Ilmiah dan Teknologi Peternakan. 3 (3): 121-125.

Rohaeni, E, S. 2015. The effects of the protein level from soybean meal and poultry meat meal on the growth of broiler chickens. Livestocks Research for rural development. 27(5).

Steel, R. G. D. dan J. H. Torrie. 1981. Principles and Procedures of Statistics. McGraw Hill Book Co., Inc., New York.

Suthama, N. 2003. Kajian aspek "Protein Turnover" tubuh pada ayam kedu periode pertumbuhan. Media peternakan. 29 (2): 47-53.

Trisiwi, H. F. 2016. Pertumbuhan kompensasi ayam betina hasil persilangan antara ayam kampung jantan dengan ayam ras petelur betina yang mendapat level protein pakan masa starter berbeda. buletin peternakan40 (2): 92-100.

Wahju, J. 2004. Ilmu Nutrisi Unggas. Gadjah Mada University Press, Yogyakarta. 